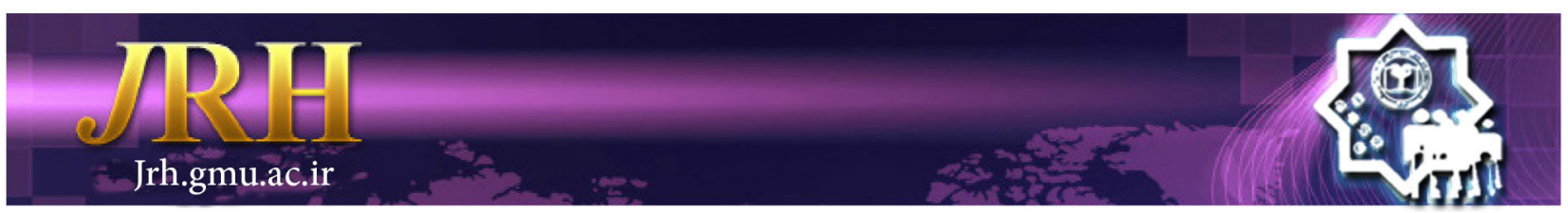

\title{
The role of demographic variables in tendency toward one-child families among married women
}

Maryam Najjar Baghsiah ${ }^{1}$, Maryam Eskafi²

Journal of Research \& Health

Social Development \& Health Promotion Research Center

Vol. 9, No. 6, Nov \& Dec 2019

Pages: $480-487$

DOI: $10.32598 /$ jrh.9.6.480

Original Article

1. Correspondence to: Department of Sosial Science, School of Sciences and Economics, Alzahra University of Tehran, Tehran, Iran Email: mn136321@gmail.com

2. Department of Social Science, School of Humanities, Islamic Azad University Gonabad Branch, Gonabad, Iran

Received: 6 Feb 2017

Accepted: 14 Apr 2019

How to cite this article: Najjar Baghsiah M, Eskafi $\mathrm{M}$. The role of the population variables in married women in the tendency of Gonabad women to have one child in 2016. $J$ Research \& Health2019; 9(6): 480 - 487.

\begin{abstract}
The fertility rate in Iran has recently changed significantly, to the point where Iran today faces a single-child phenomenon. The purpose of this study was to determine the role of demographic variables in the tendency for one child phenomenon of married women. In this study 200 married women participated whit a random sample selection from health centers. The inclusion criteria were to select married women who had one child and had at least 10 years of married life. The data collection instruments were a questionnaire to examine demographic variables (age, education, women's employment, etc.) in the tendency towards a phenomenon of one child. The results showed that more than $70 \%$ of participants did not consider one child to be ideal and only $32 \%$ tended to have one child. MANOVA test results showed that the tendency to have one child had a significance to education. Other results showed that only child planning and women's employment were correlated and forced to have one child. The overall conclusion is therefore that, while most women tend not to have one child, society's current conditions are such that women are forced to work, making them plan for the number of their children.
\end{abstract}

Keywords: Child, Demographic, Family, Women

\section{Introduction}

A look at world changes shows that women's fertility has changed dramatically in the last three decades [1]. One of the most exceptional cases in the world in recent decades is the rapid decline in fertility in Iran [2]. The birth rate and average family size decreased significantly during the 20th century. This decrease in the fertility index includes families of single parents [3]. One of the results showed that low fertility is due to the emergence of single-parent families in developed countries [4]. A more or less abnormal single-child approach has been assessed over the course of history; it has also looked abnormal [3] Various factors, such as employment for women, the availability of contraceptives and health facilities, free abortion laws, increased living expenditure, including the cost of medical care and education, changes in attitudes and behavior in the development of single - child phenomena [4]. McDonald considers low fertility to be "the result of improvements and fundamental progress in the nature and position of women in 
society"[5]. Research results show that working women face childbearing problemsboth internally and externally-that change their approach to less children as a lifestyle [6]. According to the latest population and housing census in 2011, "the country's population growth rate between 2007 and 2011 ranged from $1.6 \%$ to $3.1 \%$, and the number of households in Iran fell to $3.6 \%$.It is expected that the annual population growth in Iran will reach 1 from 2010 to 2030 with the continued decline in fertility below the succession level (1.2 children per couple) [7]. One study found that the challenges leading to single parenting include adequate organizational support, challenges in time management, being away from the family of the mother, working mothers, continuing education for women, being alone, difficult birth problems and economic problems [8]. The demographic transition theory, which is the beginning of most economic, social and other developments in the world, is one of the well-known demographic theories. In the population's first upward transition, population growth was a fundamental problem in the world, but this phenomenon was reversed with the entry into the second transition phase. One of the second demographic theories' main assumptions is that low fertility is the direct consequence of society modernization and industrialization. In parallel with the industrialization of societies and the declining health and quality of life, death rates have fallen. A common indicator of this theory and theories explaining the decline in fertility include: Increasing the age of marriage, using family planning tools, increasing divorce, increasing women's education and position, increasing individualism, focusing on work, preferring professional employment to parenting, all of which led to a decline in fertility and satisfied families with only one or two children. Mason believed that women's education enables them to have more power and independence in families with a traditional gender-based form and even in a more balanced form, and this power enables them to control more aspects of life of and the possibility of expressing opinions, as well as their ideas on issues affecting themselves and their families [5]. Giboy believed that the independence of women is one of the causes of a decline in fertility in society and has different dimensions for women's independence in behavior. 1) Information Independence: The access of women to new information within the community creates a kind of independence for them. 2) Autonomy in decision-making: Education, teaching fields for job creation, strengthening women's ideas and opinions in welfare decisions. This leads to increased fertility decision-making power for women. 3) Physical independence: Educated women have a stronger relationship with the world around them. Women's studies have greater freedom of movement and greater confidence in the use of existing services. 4) Emotional independence: There is a fairer relationship between couples and a more sincere relationship between them and their children, which makes women more aware of their value and less deny themselves 5) Economic and social independence: In economic conditions, teaching increases the self-esteem of women [9]. According to Van der Dachs, a population-based transition influences "general changes in value systems" has created changes in birth control methods that have made women pregnant only when they want to, after observing certain principles. In fact, methods of birth control are somehow explored in the theory of propagation. This theory states that one of the factors that reduced fertility is the use of contraceptives. If people are involved in the market and the urban community, family planning is common and the family dimension continues to decrease [10].

Due to changes in industrial societies, family research is crucial. Since parenting is one of the family's functions and, on the other hand, many family functions have undergone fundamental changes with the 
advent of societies in the industrial era. There is a prevalence of "single child" in the country today, and statistics show that families with one child are growing. The problem facing single- child sociologists is the collapse of the country's demographic structure in the coming years. One of the social problems associated with the single - child phenomenon is the movement of Iran's demographic curve towards aging and the lack of human resources in the decades ahead. If a developing country like Iran does not stop its declining population growth, it will face a major problem of population aging and a drastic population reduction in the next few years, which will cost the country's economy a great deal. One child's goal has influenced people and also influenced the community; one child affects the mind and soul of the child and makes the child less confident in his social relationships with others. Since fertility in this research is a multimodal behavior, especially in a small town like Gonabad, it can be examined at micro and macro and levels. Therefore, the fertility behavior was explained using the Baudon's model using the ideas and results of research and questionnaires.

\section{Method}

The study population consisted of married women who had health records at the health centers of Gonabad (Razavi Khorasan Province, Iran) in 2016 and had a child over 4 years old. The sample size was estimated using the Cochran formula at 95\% likelihood and a finally $6 \%$ was drop in 189 single-child households. 189 questionnaires randomly were distributed among single-child families. A researcher-made questionnaire was used for collecting data in this survey which was focused on the study's goals and conceptual framework (based on existing theories and previous research) and qualitative results. The questionnaire consisted of 19-item in two sections. The first section involves demographic and individual characteristics, including seven items (income, female education, women's work, age of first pregnancy, single-child planning or otherwise, coercion for the single child). The second part of the study was the tendency to have a single-child with 10 items and 2 questions (the tendency towards a single-parenting, ideological knowing and not speaking of the single child). The questions included a five-point Likert scale which vary from strongly agrees to strongly disagree. Finally, "Cronbach's alpha" with 0.71 confirmed the reliability of this questionnaire. Single-variable covariance and multivariate variance analysis (MANOVA) were used to analyze data by using SPSS-20. The significance level in this study was $p<0.05$.

\section{Results}

Based on demographic results, $46.6 \%$ of study respondents were under 34 years old, $43.8 \%$ were $35-44$ year old, $5.1 \%$ were 45-55 years of age and $4.5 \%$ were over 55 years old. $21.9 \%$ of respondents were under 20 and $34.8 \% 21-26,29.8 \%$ between $27-31$ and $13.5 \%$ over 32 when they gave birth to their children. $2.8 \%$ of Women were unemployed, while $53.9 \%$ were employed. Of these, $43.3 \%$ were housewives. $22.5 \%$ of females had no diploma, while $38.8 \%$ had diploma. $28.1 \%$ of females had an associate diploma and $10.6 \%$ had bachelor and higher education.

To determine the significance of each independent model variable, Table 2 shows the results of four multivariate tests. Based on Table 2, each of the four tests is relevant to the effects of female educational variables, one child planning, female occupation, and two planning variables for one child and one child compulsion, but none of the tests were significant for the other independent variables not included in Table 2.

As shown in Table 3, the independent variable explains more than $0.33 \%$ of the differences of the first dependent variable (single-child tendency) and about 34\% of the variants of the second dependent variable (single-child ideals). 
Table 1 Demographic variables of the participants

\begin{tabular}{|c|c|c|c|}
\hline & & Number & Percentage \\
\hline \multirow{4}{*}{ Age } & Under 34 & 83 & 46.6 \\
\hline & $35-44$ & 78 & 43.8 \\
\hline & $45-54$ & 9 & 5.1 \\
\hline & Higher than 55 & 8 & 4.5 \\
\hline \multirow{4}{*}{ Income } & 1000000 & 79 & 44.4 \\
\hline & $1000000-1500000$ & 6 & 3.4 \\
\hline & $1500000-2000000$ & 46 & 25.8 \\
\hline & Higher than 2000000 & 47 & 26.4 \\
\hline \multirow{4}{*}{$\begin{array}{l}\text { The age of } \\
\text { first pregnancy }\end{array}$} & below 20 & 40 & 21.9 \\
\hline & $21-26$ & 69 & 34.8 \\
\hline & $27-31$ & 50 & 29.8 \\
\hline & Higher than 32 & 19 & 13.5 \\
\hline \multirow{4}{*}{$\begin{array}{l}\text { Women's } \\
\text { Education }\end{array}$} & Not Having Diploma & 40 & 22.5 \\
\hline & Diploma & 69 & 38.8 \\
\hline & Associate diploma & 50 & 28.1 \\
\hline & Bachelor and higher & 19 & 10.6 \\
\hline \multirow{3}{*}{$\begin{array}{l}\text { The Woman's } \\
\text { Occupation }\end{array}$} & Unemployed & 5 & 2.8 \\
\hline & Employed & 96 & 53.9 \\
\hline & housewife & 77 & 43.3 \\
\hline \multirow{5}{*}{$\begin{array}{l}\text { Tendency to } \\
\text { have one child }\end{array}$} & Too much & 16 & 9.0 \\
\hline & Much & 21 & 11.8 \\
\hline & Average & 40 & 22.5 \\
\hline & Few & 44 & 24.7 \\
\hline & Too few & 57 & 32.0 \\
\hline
\end{tabular}

Table 2 The results of the multivariables tests ans independents variables effects on dependents variables

\begin{tabular}{|c|c|c|c|c|c|c|c|}
\hline & & Value & $\mathrm{F}$ & $\begin{array}{l}\text { Degree of } \\
\text { freedom of } \\
\text { hypothesis }\end{array}$ & $\begin{array}{l}\text { Degree of } \\
\text { freedom } \\
\text { of error }\end{array}$ & $\begin{array}{l}\text { Significance } \\
\text { level }\end{array}$ & Eta Squ. \\
\hline \multirow{4}{*}{$\begin{array}{l}\text { Dependent } \\
\text { variable }\end{array}$} & Pillai's Trace & 0.377 & $48.691^{b}$ & 2.000 & 161.000 & 0.000 & 0.377 \\
\hline & Wilks’ Lambda & 0.623 & $48.691^{\mathrm{b}}$ & 2.000 & 161.000 & 0.000 & 0.377 \\
\hline & Hotelling's Trace & 0.605 & $48.691^{\mathrm{b}}$ & 2.000 & 161.000 & 0.000 & 0.377 \\
\hline & Roy's Largest Root & 0.605 & $48.691^{\mathrm{b}}$ & 2.000 & 161.000 & 0.000 & 0.377 \\
\hline \multirow{4}{*}{$\begin{array}{l}\text { Women's } \\
\text { education }\end{array}$} & Pillai’s Trace & 0.072 & $6.289^{\mathrm{b}}$ & 2.000 & 161.000 & 0.002 & 0.072 \\
\hline & Wilks' Lambda & 0.928 & $6.289^{b}$ & 2.000 & 161.000 & 0.002 & 0.072 \\
\hline & Hotelling's Trace & 0.078 & $6.289^{\mathrm{b}}$ & 2.000 & 161.000 & 0.002 & 0.072 \\
\hline & Roy's Largest Root & 0.078 & $6.289^{b}$ & 2.000 & 161.000 & 0.002 & 0.072 \\
\hline \multirow{4}{*}{$\begin{array}{l}\text { Planning for one } \\
\text { child }\end{array}$} & Pillai’s Trace & 0.257 & 11.940 & 4.000 & 324.000 & 0.000 & 0.128 \\
\hline & Wilks' Lambda & 0.753 & $12.283^{b}$ & 4.000 & 322.000 & 0.000 & 0.132 \\
\hline & Hotelling's Trace & 0.316 & 12.622 & 4.000 & 320.000 & 0.000 & 0.136 \\
\hline & Roy's Largest Root & 0.267 & $21.658^{c}$ & 2.000 & 162.000 & 0.000 & 0.211 \\
\hline \multirow{4}{*}{$\begin{array}{l}\text { Women's } \\
\text { occupation }\end{array}$} & Pillai’s Trace & 0.218 & 9.913 & 4.000 & 324.000 & 0.000 & 0.109 \\
\hline & Wilks' Lambda & 0.782 & $10.535^{\mathrm{b}}$ & 4.000 & 322.000 & 0.000 & 0.116 \\
\hline & Hotelling's Trace & 0.279 & 11.154 & 4.000 & 320.000 & 0.000 & 0.122 \\
\hline & Roy's Largest Root & 0.279 & $22.577^{\mathrm{c}}$ & 2.000 & 162.000 & 0.000 & 0.218 \\
\hline \multirow{4}{*}{$\begin{array}{l}\text { Planning for } \\
\text { having one child } \\
\text { and being forced } \\
\text { to have one child }\end{array}$} & Pillai's Trace & 0.107 & $9.602^{b}$ & 2.000 & 161.000 & 0.000 & 0.107 \\
\hline & Wilks' Lambda & 0.893 & $9.602^{\mathrm{b}}$ & 2.000 & 161.000 & 0.000 & 0.107 \\
\hline & Hotelling's Trace & 0.119 & $9.602^{b}$ & 2.000 & 161.000 & 0.000 & 0.107 \\
\hline & Roy's Largest Root & 0.119 & $9.602^{\mathrm{b}}$ & 2.000 & 161.000 & 0.000 & 0.107 \\
\hline
\end{tabular}


Demographic variables in tendency to one child

Table 3 The results of the test influences among the variables

\begin{tabular}{|c|c|c|c|c|c|c|c|}
\hline $\begin{array}{l}\text { The source of } \\
\text { variations }\end{array}$ & Independent variable & Ss & $\mathrm{df}$ & Ms & $\mathrm{F}$ & $\begin{array}{c}\text { Significance } \\
\text { level }\end{array}$ & Eta Squ. \\
\hline \multirow{2}{*}{ Reformed } & Tendency to have one child & $114.644^{\mathrm{a}}$ & 15 & 7.643 & 6.863 & 0.000 & 0.389 \\
\hline & Thinking of having one child as ideal & $8661.020^{\mathrm{b}}$ & 15 & 577.401 & 7.028 & 0.000 & 0.394 \\
\hline \multirow{2}{*}{ Tracking } & Tendency to have one child & 89.545 & 1 & 89.545 & 80.404 & 0.000 & .332 \\
\hline & Thinking of having one child as ideal & 1364.294 & 1 & 1364.294 & 16.605 & 0.000 & 0.093 \\
\hline \multirow{2}{*}{$\begin{array}{l}\text { Women's } \\
\text { occupation }\end{array}$} & Tendency to have one child & 0.715 & 1 & 0.715 & 0.642 & 0.424 & 0.004 \\
\hline & Thinking of having one child as ideal & 980.982 & 1 & 980.982 & 11.940 & 0.001 & 0.069 \\
\hline \multirow{2}{*}{$\begin{array}{l}\text { Planning for } \\
\text { having one child }\end{array}$} & Tendency to have one child & 21.337 & 2 & 10.669 & 9.580 & 0.000 & 0.106 \\
\hline & Thinking of having one child as ideal & 2661.600 & 2 & 1330.800 & 16.197 & 0.000 & 0.167 \\
\hline \multirow{2}{*}{$\begin{array}{l}\text { Women's } \\
\text { occupation }\end{array}$} & Tendency to have one child & 1.360 & 2 & 0.680 & 0.610 & 0.544 & 0.007 \\
\hline & Thinking of having one child as ideal & 3626.209 & 2 & 1813.104 & 22.067 & 0.000 & 0.214 \\
\hline \multirow{2}{*}{$\begin{array}{l}\text { Planning for } \\
\text { having one child } \\
\text { and being forced } \\
\text { to have one child }\end{array}$} & Tendency to have one child & 21.517 & 1 & 21.517 & 19.321 & 0.000 & 0.107 \\
\hline & Thinking of having one child as ideal & 0.006 & 1 & 0.006 & 0.000 & 0.993 & 0.000 \\
\hline
\end{tabular}

\section{Discussion}

The results of this study showed that over $70 \%$ of sample members do not consider a single family of children to be ideal and about $50 \%$ choose to have two children. In this regard, the results of the current study are consistent with the results of other studies on individual attitudes towards the number of children in the family in which $(31.7 \%)$ one child $(50 \%)$ reported more than two children (18.3\%). This study suggests that most parents think that having two children is ideal [7]. Female occupation, one child planning, and one child planning and being forced to have one child are more than $33 \%$ of dependent variable variations and about $34 \%$ of the tendency towards have one child as an ideal among variables in the female educational field. In Nepal, Kashumi and Bekata concluded that the use of contraceptives, industrialization, social and economic changes such as increase in marriage age, increasing of education, independence, immigration, and abortion are effective factors in reducing fertility [11]. Another study concluded that a decrease in fertility resulted in increased nomadic education [12]. Other research results have shown that there is a significant negative relationship between women's education level and the ideal number of children [13]. In another study, researchers showed that the independent variable influenced the tendency to give birth to women between the ages of 15 and 29, and the tendency to childbirth decreased with the increase in independence; however, the desire to have more children was influenced by the age of 40-49. [14]. One of the findings of the research showed that women considered their physical, psychological and social conditions to be the reason for the tendency to have fewer children. The achievement of a good job and the use of social opportunities is one of the aspects of such self-support [15]. Women's occupation in international research in France has also been identified as a factor in having one child [16]. The results of this study showed that a woman's type of work tends to have one child.

Another result was the planning behavior for the number of children affecting one child. The results showed that the planned theory of behavior can help us understand fertility decisions better. Behavioral and normative studies and control of a child's beliefs are important factors that affect this decision. The data can lead to a policy that encourages or prevents couples from having more children 
[17]. Another research showed that three elements of attitudes, mental standards, and regulated behavior understanding introduce the reason why there is no inclination to have

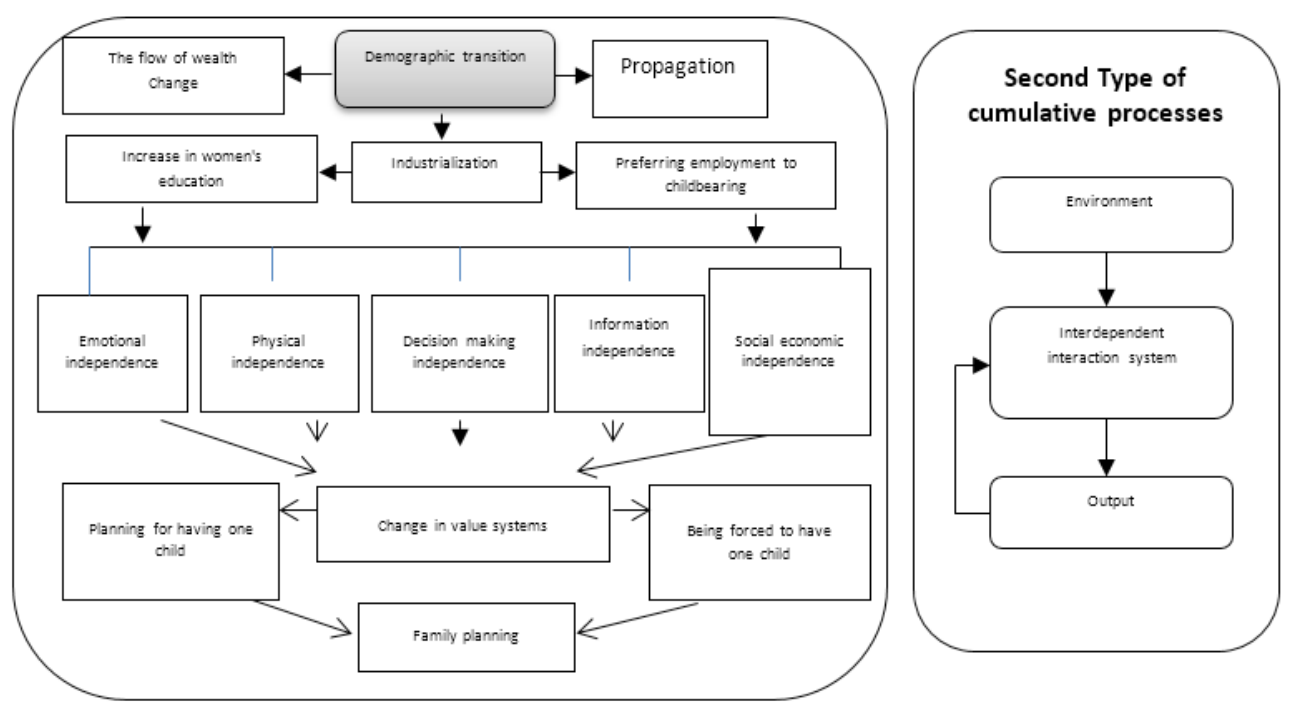

Figure 1 Cumulative process model of Baudon (right) applying social phenomenon of having one child in Baudon model (left)

a second child [18]. The qualitative results of the research showed that, according to the theory of planned behavior in the field of family formation, social standards, attitudes, and social control are significantly related to the intention of fertility, and quantitative results indicate that the intention of fertility is ready to give birth to men and women without children [19].

Based on Baudon's cumulative method, the tendency to have one child was explained using the thoughts used in this field and the results acquired from the studies as well as considering Raymond Baudon's sociological theory of transformation. The environment, the interdependent system, and results are its foundations in this process (Figure 1, Baudon's second type of cumulative processes) and can be used as a model to analyze these social issues.

One of the study's limitations was access to eligible women with regard to the subject of studies. Another limitation dealt with the selection of appropriate theory and theoretical framework corresponding to the subject of research. According to the results, one of the considerations why females wanted to have one child was their employment and education; thus, fertility could be improved with legislation to decrease working hours for women. Because families consider the desirable number of children to be one or two, family attitudes can be changed through the media.

\section{Conclusion}

Social man can not always act on his priorities, but he acts on the habits, internal values and, more generally, different moral, cognitive and formal conditions. For social people, at least part of an activist's choices is assumed to be determined by the structure of social position and status in this position. In the other hand, Wealth flows from children to parents in traditional societies. Children were considered the basic goods and the main source of income in these societies. But this flow of wealth is reversed in modern societies, and children are less interested in parents and more cost - effective. Environmental, economic, social and biological factors are the second indirect factor affecting the reduction of fertility and as a result of changing the environment on the basis of the second theory of demographic transition, It leads to an increase in women's education and position, an increase in 
individualism, orientation towards work, preference for careers in child- rearing, which in turn has reduced fertility.

\section{Acknowledgements}

This article is derivative from thesis of the master's degree belong to the first author of the Alzahra university. The authors gratitude all participants for their cooperation.

This article is derived from the research project code 564/1/5/95, dated June 8th 2019, from Alzahra University

\section{Authors' contributions}

Study Design: MNB

Data collection and analysis: MNB, ME

Manuscript preparation: MNB

All authors have read and approved the final version.

\section{Conflict of Interest}

"The authors declare that they have no competing interests."

\section{Funding}

The author (s) received no financial support for the research, authorship and/or publication of this article.

\section{Availability of data and materials}

The datasets used and/or analyzed during this study are available from the corresponding author on reasonable request.

\section{References}

1- Mohammadi N, Saifuri B. Sociological study of the factors affecting women's fertility preference. Journal Cultural-Educational of Women and Families2016; 11(36): 49-70.

2- Khalajabadi-Farahani F, Saraie H. Intention for single child and its determinants amongst men and women owned one child under five in Tehran. Journal of Population Association of Iran2012; 7(13): 118-48.

3- Adler A. Nervous problems. New York: Harperd and row; 1964.

4- Itismita Pradhan T, Sekher V. Single-child families in India: levels, trends and determinants. Asian Population Studies2014; 10(2): 163-75.

5-Abbasi-Shavazi M, Mundgary M. The effects of various dimensions of women's autonomy on fertility behavior in Iran. Women in Development \& Politics2011; 8(1): 31-51.

6- Eshagh M, Mohebbi F, Papynezhad SH, Jahandar

Z. Childbearing challenges for working women; a qualitative study. Women in Development \& Politics2015; 12(1): 111-34.

7- Mobasheri M, Alidousti M, Heidari Souresjani S, Khosravi F, Khalafeyan P, Jalilian M. Determination of most important factors influencing the fertility patterns of single child and without child families in Shahr-e Kord. Journal of Ilam University of Medical Sciences2014; 21(6): 70-64.

8- Jahangiri J, Ahmadi H, Tabiee M, Moltafet H. Construction of one- child women understanding of childbearing challenges (Participants: one- childwomen of Ahvaz). Journal of Human Development 2015; 9(1): 85-110.

9- Samakar N. Factors affecting the attitude of the single child of women marriage in Tehran. [thesis]. domogrphics. Tehran: Allameh Tabatabaei university 2012. pp: 190.

10- Adibisade M, Siahpoosh AA, Darvishzadeh. A study of the effect of population growth on per capita gdp in Iran using an approach. Journal of Iranian Social Development Studies2012; 4(1): 81-98.

11- Shakya K, Gubhaju B. Factors contributing to fertility decline in Nepal. Journal of Population and Social Studies2016; 24(1): 13- 29.

12- Keshavarz H, Bahramian M, Mohajerani A, Hosseinpour K. Factors effective in changing of reproductive behaviors of nomadic and non-nomadic tribes in the semirom province, Iran. Journal of Health System Research2013; 8(3): 456-65.

13- Moshfegh M, Ghreb Eshgee S. An analysis on relationship between the value of children and fertility among Tehran's women. Strategic Studies Women2013; 15(58): 93-120.

14- Abbasi-Shavazi M, Khaje Salehi Z. Independent impact assessment, community involvement and education tend to childbearing women (Case study: Sirjan). Women in Development \& Politics2014; 11(1): 45-64.

15- Mahmoodian H, Rezaie M. Women and low childbearing action: the case study of kurdish women. Strategic Studies Women2013; 14(55): 174-225.

16- Breton D, Prioux F. The one child family: France in the European context. Demographic Research2009; 20: 657-92

17- Ajzen I, Klobas J. Fertility intentions: An approach based on the theory of planned behavior. Demographic Research2013; 29(8): 203-32.

18- Silvagni MG. Why not the second child? an economic analysis of fertility behaviour of russian parents. IZA/ HSE Workshop, October 5-6 2012. Moscow. 
19- Buber I, Fliegenschnee K. Are you ready for a child? A methodological triangulation on fertility intentions in Austria. Austrian: Vienna institute of demography working paper; 2011.

20- Ritzer G. Contemporary sociological theory. New York: Knopf; 1988

21- Boudon R. The logic of social action. London: Routledge Kegan \& Paul; 1981
22- Oktayi R. Review of socio economic and cultural issues affecting the fertility rate with emphasis on the role of family planning in Isfahan. [thesis]. sociology, social sciences. Isfahan: University of Isfahan 2006.

23- Ziaie Bigdeli M, Kalantari S, Alizade Aghdam $\mathrm{M}$. the relationship between fertility rate and socioeconomic development. Journal of Social Welfare2007; 5(12): 123-40.

Copyright $\odot 2016$ ASP Ins. This open-access article is published under the terms of the Creative Commons Attribution-NonCommercial 4.0 International License which permits Share (copy and redistribute the material in any medium or format) and Adapt (remix, transform, and build upon the material) under the Attribution-NonCommercial terms. 